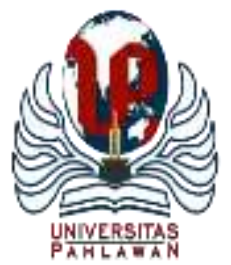

Edukatif : Jurnal Ilmu Pendidikan Volume 3 Nomor 6 Tahun 2021 Halm 3866 - 3876

EDUKATIF: JURNAL ILMU PENDIDIKAN

Research \& Learning in Education

https://edukatif.org/index.php/edukatif/index

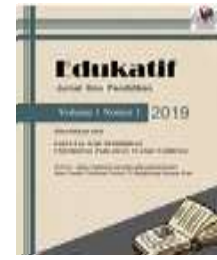

\title{
Pengembangan Aplikasi Mobile Learning Appy Pie Android Berbasis Kemampuan Berpikir Kreatif di Sekolah Dasar
}

\author{
Nur Auliyah ${ }^{1 凶}$, Prima Mutia Sari ${ }^{2}$ \\ Universitas Muhammadiyah Prof. Dr. HAMKA, Indonesia ${ }^{1,2}$ \\ E-mail : nur.auliyah@uhamka.ac.id ${ }^{1}$, primamutiasari@uhamka.ac.id ${ }^{2}$
}

\begin{abstract}
Abstrak
Penelitian ini bertujuan untuk mengetahui kualitas kelayakan aplikasi mobile learning android berbasis kemampuan berpikir kreatif pada materi Perubahan Wujud Benda. Metode penelitian yang digunakan ialah Research and Development dengan model pengembangannya menggunakan ADDIE yang memiliki lima tahap yaitu analisis, desain, pengembangan, implementasi, dan evaluasi. Instrumen yang digunakan dalam penelitian menggunakan lembar penilaian dari ahli materi, ahli media, penilaian guru, dan uji coba siswa. Penelitian ini diujicobakan kepada 32 siswa kelas III pada salah satu sekolah dasar di Jakarta Timur. Hasil penelitian menunjukkan bahwa dari validasi ahli materi mendapatkan persentasi sebesar $88.50 \%$, selanjutnya hasil validasi oleh ahli media dengan persentase sebesar $89.84 \%$, dan hasil penilaian oleh guru didapatkan persentase sebesar $87.50 \%$. Uji coba dilakukan pada siswa diperoleh persentase kualitas media pembelajaran sebesar 79.25\% dengan kategori layak. Berdasarkan hasil perolehan data menunjukkan bahwa aplikasi mobile learning Appy Pie Android berbasis kemampuan berpikir kreatif layak digunakan sebagai media pembelajaran siswa kelas III sekolah dasar.
\end{abstract}

Kata Kunci: Mobile Learning, Appy Pie, Model ADDIE.

\begin{abstract}
The purpose of this development research is to determine the quality and feasibility of an android mobile learning application based on creative thinking skills in the subject of Change in Objects. The method of the research is Research and Development with the development ADDIE model which has five stages, analysis, design, development, implementation, and evaluation. Instrument of this research is based on the results of research by media experts, material experts, teacher assessments, and test on students. This research was tested on 32 third grade students at one of the State Elementary School at East Jakarta. The results showed that from the validation of the material experts, a percentage of $88.50 \%$ was obtained, then the results of the validation by media experts with a percentage of $89.84 \%$, and the results of the assessment by the teacher obtained a percentage of $87.50 \%$. The test was carried out on students, the percentage of learning media quality was $79.25 \%$ with feasible category. Based on the results of data acquisition, the Appy Pie Android mobile learning application based on creative thinking skills is appropriate to be used as a learning media for third grade elementary school students.
\end{abstract}

Keywords: Mobile Learning, Appy Pie, The ADDIE Model.

Copyright (c) 2021 Nur Auliyah, Prima Mutia Sari

$\triangle$ Corresponding author

Email : nur.auliyah@uhamka.ac.id

DOI : https://doi.org/10.31004/edukatif.v3i6.1127

ISSN 2656-8063 (Media Cetak)

ISSN 2656-8071 (Media Online) 
3867 Pengembangan Aplikasi Mobile Learning Appy Pie Android Berbasis Kemampuan Berpikir Kreatif di Sekolah Dasar - Nur Auliyah, Prima Mutia Sari

DOI: https://doi.org/10.31004/edukatif.v3i6.1127

\section{PENDAHULUAN}

Berdasarkan surat edaran Nomor 4 Tahun 2020 tentang pelaksanaan kebijakan pendidikan dalam masa darurat penyebaran Corona Virus Disease, aktivitas di dunia pendidikan meliputi kegiatan pembelajaran dilaksanakan secara daring untuk mengurangi rantai penyebaran virus (Menteri Pendidikan dan Kebudayaan, 2020). Pemerintah mengupayakan pembelajaran jarak jauh atau PJJ sebagai pembiasaan baru agar siswa dapat beradaptasi dengan pandemi COVID -19. Dalam pelaksanaannya, proses pembelajaran online ditemui beberapa masalah yang terjadi, ditinjau dari hasil evaluasi Kemendikbud mengenai kegiatan PJJ per April 2020, hanya 51\% kegiatan PJJ yang berjalan efektif. Permasalahan yang terjadi antara lain seperti siswa-siswi yang tidak memiliki akses teknologi, keterbatasan alat/gawai, kondisi jaringan internet, serta kurangnya aplikasi/media pembelajaran (Indahri, 2020). Selain itu, selama kegiatan PJJ guru hanya menggunakan media pembelajaran powerpoint dan metode yang metode ceramah yang bersifat konvensional sehingga kurang interaktif. Hal ini mengakibatkan siswa pasif dalam mengikuti pembelajaran. (Wiro \& Sulistyowati, 2021). Dari berbagai permasalahan tersebut, diperlukan peran guru untuk melakukan inovasi menghadapi pembelajaran jarak jauh. Pengembangan media pembelajaran yang edukatif dan mampu menstimulus proses berpikir kreatif yang merupakan salah satu indikator dari 4 kemampuan yang dibutuhkan pada Abad ke 21 ini (Ningsih, 2021). Kemampuan berpikir kreatif berupaya agar siswa mampu mengaplikasikan hasil pemikiran dalam kesehariannya. Kreativitas siswa akan berkembang dengan baik jika dilandasi oleh faktor - faktor berikut : (1) sikap yang merangsang psikis dan stabilitas mental, lingkungan sekitar yang kondusif, guru sebagai fasilitator yang berperan menstimulus kreativitas anak untuk mengeksplorasi kreativitasnya (Septikasari, 2018).

Solusi untuk peningkatan kemampuan berpikir kreatif siswa adalah dengan mengembangan materi yang edukatif dan mudah diakses oleh siswa yaitu melalui pengembangan mobile learning. Menurut Darmawan, dalam mobile learning dalam yang kegiatan belajar mengajar tidak terhalang ruang dan waktu (Rahmat, 2019). Sehingga, siswa dapat mengeksplorasi materi dan dapat belajar secara mandiri walaupun berada di rumah. Dalam (Wulandari et al., 2019) juga menjelaskan, melalui konsep mobile learning pembelajaran dapat berjalan sacar fleksibel dan portable, sehingga siswa memiliki kesempatan belajar secara lebih mudah, relevan dan secara lebih menyenangkan. Pengembangan mobile learning berbasis android dapat memuat berbagai fitur bermanfaat bagi kegiatan pembelajaran seperti muatan materi pembelajaran, ringkasan materi, latihan, video dan animasi, serta fitur - fitur menarik lainnya.

Untuk mengembangkan mobile learning dapat dilakukan dengan menggunakan berbagai software seperti MIT App Inventor, iSpring Suite 88, Appy Pie, dan lain-lain. Penelitian ini menggunakan www.appypie.com untuk mengembangkan aplikasi pembelajaran. Pemilihan Appy Pie sebagai website pengembangan adalah proses penyusunan aplikasi dapat dilakukan tanpa proses coding atau tanpa menggunakan bahasa pemrograman. Penyediaan desain dasar telah difasilitasi oleh pihak Appypie sehingga pengguna pemula dapat dengan mudah mengembangkan aplikasi sesuai kebetuhannya (Chusni \& dkk, 2018). Dari kelebihan ini dasar pertimbangan peneliti untuk menggunakan Appy Pie sebagai app builder mobile learning yang bermanfaat bagi kegiatan belajar di kelas III di salah satu Sekolah Dasar di Jakarta Timur.

Berdasarkan deskripsi uraian latar belakang tersebut menjadi faktor - faktor yang melandasi penelitian pengembangan aplikasi mobile learning menggunakan Appy Pie berbasis kemampuan berpikir kreatif siswa mengenai materi perubahan wujud benda. Lahirnya penelitian ini berpedoman pada hasil kajian dan analisis dari penelitian terdahulu, beberapa penelitian yang mengangkat topik yang sama diantaranya adalah penelitian yang dilakukan oleh (Ratnasari et al., 2020) dengan judul penelitian "Pengembangan Mobile Learning Berbasis Appy Pie untuk Pembelajaran Fisika" berdasarkan hasil penelitian diperoleh hasil validasi media sebesar $90 \%$ sedangkan ahli materi dengan persentase sebesar $84 \%$. Melalui penelitian ini, siswa yang kesulitan dalam mempelajari materi fisika dapat dengan mudah mengakses materi melalui aplikasi yang di 
dalamnya telah dilengkapi oleh video pembelajaran. Namun dalam pengembangan penelitian ini mobile learning tidak terhubung dengan Play Store serta gambar dan tulisan tidak bisa disesuaikan denga kebutuhan tampilan. Uraian pelaksanaan penelitian dalam (Ratnasari et al., 2020) memiliki kesamaan dengan penelitian yang saat ini dilakukan yaitu mengenai penggunaan Appy Pie untuk mengembangkan aplikasi mobile learning. Namun fokus penelitian ini terkait penggunaan aplikasi mobile learning bagi siswa jenjang sekolah dasar pada materi perubahan wujud benda sehingga siswa dapat belajar secara mandiri dan meningkatkan kemampuan berpikir kreatif melalui aplikasi mobile learning yang dikembangkan. Terdapat pula penelitian lain yang mengungkapkan bahwa pemahaman konsep siswa mengalami peningkatan pada materi sistem peredaran darah berdasarkan hasil pretest dan posttest penggunaan aplikasi mobile learning. Siswa memberikan respon positif terhadap uji coba penggunaan aplikasi dengan penilaian pada aspek media sebesar $81,5 \%$ aspek penyajian materi dengan persentase $81 \%$ dan aspek manfaat dengan persentase $94 \%$. Hasil uji coba pada penelitian ini menunjukkan penilaian aplikasi mobile learning dikategorikan sangat baik (Widiastika \& dkk, 2021). Jika pada penelitian (Widiastika \& dkk,, 2021) membahas mengenai penggunaan mobile learning dalam peningkatan pemahaman konsep materi peredaran darah, penelitian yang saat ini meneliti penggunaan aplikasi mobile learning pada materi perubahan wujud benda.

Meninjau rujukan pelaksanaan penelitian yang telah dilakukan sebelumnya, memberikan gagasan peneliti untuk melakukan penelitian terkait pengembangan aplikasi mobile learning yang berfungsi sebagai media pembelajaran dalam kegiatan pembelajaran mandiri siswa, sehingga siswa dapat mengeksplorasi materi dan meningkatkan kemampuan berpikir kreatif. Penelitian ini penting untuk dilaksanakan karena bertujuan untuk meneliti bagaimana pengembangan aplikasi mobile learning berbasis berpikir kreatif pada materi perubahan wujud benda. Penelitian ini akan menguji kelayakan aplikasi mobile learning, serta bagaimana respon guru dan peserta didik terhadap penggunaan aplikasi mobile learning berbasis kemampuan berpikir kreatif menggunakan Appy Pie pada materi wujud benda kelas III sekolah dasar.

\section{METODE PENELITIAN}

Pelaksanaan penelitian ini menggunakan metode penelitian dan pengembangan atau Research and Development (R\&D) dengan model ADDIE. Jika ditinjau secara definisi, penelitian dan pengembangan (research and development) merupakan bentuk penelitian yang menghasilkan produk tertentu dan kemudian diuji apakah produk yang dihasilkan efektif atau tidak dalam penggunaannya (Setyosari, 2015). Penggunaan ADDIE sebagai model penelitian dikarenakan model penelitian ini sederhana dan mudah dipelajari. Struktur pelaksanaannya tersusun secara sistematis dan sesuai dengan kebutuhan penelitian pengembangan. Subyek pada penelitian ini adalah siswa kelas III pada salah satu sekolah dasar di Jakarta Timur. Penelitian ini dilaksanakan pada bulan Juni sampai bulan Juli 2021. Instrmen yang digunakan dalam penelitian ini adalah angket kuesioner ahli validasi media, angket kuesioner ahli validasi materi, angket kuesioner penilaian kelayakan guru dan lembar kuesioner uji coba siswa. Metode pengumpulan data dalam penelitian ini adalah dengan observasi, wawancara dengan guru, dan penyebaran lembar angket validasi produk. Pelaksanaan analisis data menggunakan analisis deskriptif dengan skala Likert berdasarkan kategori yang ditentukan, sedangkan hasil observasi dan wawancara dilakukan analisis data secara kualitatif.

Output yang dikembangkan dalam penelitian ini yaitu aplikasi mobile learning yang akan digunakan sebagai media pembelajaran bagi siswa. Adapun tahapan dalam model penelitian ADDIE (Sugiyono, 2018) adalah sebagai berikut : 


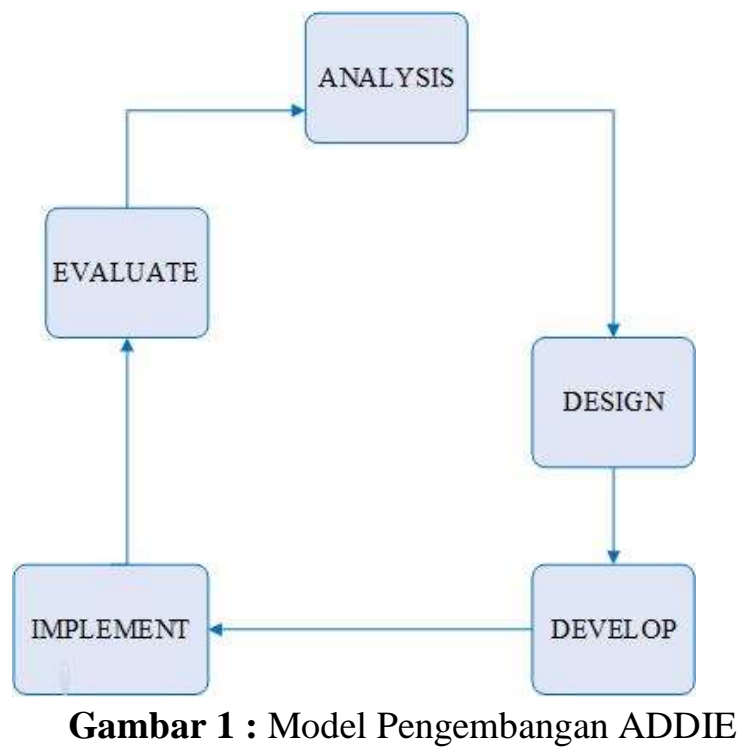

Tahap pertama dari model pengembangan ADDIE adalah pelaksanaan analisis (Analysis). Pada tahap ini, dilakukan analisis permasalahan pembelajaran yang dihadapi siswa, analisis kubutuhan dan identifikasi masalah yang dihadapi guru, serta melakukan analisis materi yang akan dikembangkan.Tahapan kedua adalah proses perancangan atau mendesain (Design). Pada tahap ini, perancangan yang dilakukan berupa desain aplikasi, penyusunan materi mencakup konsep pembelajaran dan bahan ajar, penentuan animasi yang sesuai serta pembuatan lembar penilaian oleh ahli validasi. Proses perancangan masih bersifat desain dasar yang akan dijadikan acuan untuk pembuatan produk pada tahap berikutnya. Proses pembuatan produk yang telah dirancang dilakukan pada tahap ketiga yaitu tahapan pengembangan (Development). Setelah produk yang telah dikembangkan telah dapat digunakan, maka akan dilakukan uji coba pada proses implementasi (Implementation). Melalui pelaksanaan penerapan atau implementasi, output produk yang sudah dikembangkan selanjutnya diuji coba pada kegiatan pembelajaran. Sebelum melakukan uji coba produk, aplikasi mobile learning yang telah dikembangkan dilakukan penilaian kelayakan melalui uji validitas. Terdapat dua ahli validasi materi dan ahli validasi media, serta penilaian oleh guru dalam penelitian ini. Uji validasi dilakukan dengan menggunakan lembar instrumen berupa skala penilaian yang diberikan kepada validator atau dosen ahli bersamaan dengan produk yang akan di uji validasi. Melalui proses validasi ini akan diketahui kelayakan produk yang dikembangakan berdasarkan tinjauan saran, masukan, dan komentar dari para ahli sehingga diperoleh penilaian kelayakan dari produk yang dikembangkan. Setelah para validator meguji kelayakan produk, Setelah tahap uji coba dilaksanakan maka tahapan terakhir yaitu melakukan uji coba produk kepada siswa kelas III pada salah satu sekolah dasar di Jakarta Timur. Tahapan final dari model ADDIE adalah melakukan evaluasi (Evaluation). Kegiatan evaluasi dilakukan setelah adanya uji coba produk dan hasil kritik dan masukkan dari para ahli mencakup ahli materi dan ahli media, guru, dan pelaksanaan uji coba oleh siswa. Dalam proses pengumpulan data penelitian, menggunakan kusioner angket pada uji validasi dan tahap uji coba. Perolehan data berupa data deskriptif kualitatif dan perhitungan hasil data kuantitatif. Perolehan data secara kualitatif diterima dari hasil penilaian para ahli berupa saran dan masukkan yang akan dijadikan acuan untuk perbaikan produk. Perolehan data berupa data kuantitatif dari perolehan penilaian dari ahli validasi. Data tersebut kemudian dikalkulasikan persentasi dari setiap aspek uji validasi untuk mengetahui apakah produk layak untuk dilakukan uji coba. Kisi - kisi instrumen validasi produk sesuai tabel berikut.

Tabel 1. 
3870 Pengembangan Aplikasi Mobile Learning Appy Pie Android Berbasis Kemampuan Berpikir Kreatif di Sekolah Dasar - Nur Auliyah, Prima Mutia Sari

DOI: https://doi.org/10.31004/edukatif.v3i6.1127

\begin{tabular}{ll}
\hline \multicolumn{1}{c}{ Kisi - Kisi Instrumen } \\
\hline \multirow{4}{*}{ Anstrumen } & \multicolumn{1}{c}{ Aspek } \\
\cline { 2 - 2 } & Materi \\
\cline { 2 - 2 } & Sumber Materi \\
\cline { 2 - 2 } & Evaluasi \\
\cline { 2 - 2 } Ahli Media & Kebahasaan \\
\cline { 2 - 2 } & Isi dan Tampilan \\
\hline \multirow{2}{*}{ Uji Kelayakan Pendidik } & Penggunaan \\
\hline \multirow{2}{*}{ Uji Coba Siswa } & $\begin{array}{l}\text { Materi dan } \\
\text { Pembelajaran }\end{array}$ \\
\cline { 2 - 2 } & Media \\
\hline
\end{tabular}

\section{Pengolahan Data}

Kegiatan uji coba kepada siswa dilaksanakan pada kelas III di salah satu sekolah dasar di Jakarta Timur dengan jumlah siswa sebanyak 32 orang. Pelaksanaan uji coba dilakukan untuk meninjau penggunaan produk yang telah dikembangkan. Penilaian dan respon dari siswa akan dirumuskan dalam bentuk kuisioner. Penyusunan kuesioner dilakukan dengan mengacu pada rating scale yang diambil dari Skala Likert (Retnawati, 2015). Tabel berikut Skala Likert yang digunakan pada penelitian:

Tabel 2.

\begin{tabular}{lc}
\hline \multicolumn{2}{c}{ Skala Skor Instrumen } \\
\cline { 2 - 3 } Kriteria & Nilai \\
\hline Sangat Baik & 5 \\
\hline Baik & 4 \\
\hline Cukup & 3 \\
\hline Tidak Baik & 2 \\
\hline Sangat Tidak Baik & 1 \\
\hline Sumber : (Jannah \& Julianto, 2018)
\end{tabular}

Pengolahan data kemudian akan dianalisis dengan cara teknik analisis deskriptif dengan melakukan perhitungan di bawah ini:

$$
\mathrm{P}=\frac{f}{n} \times 100 \%
$$

Keterangan :

$\mathrm{P}=$ Persentase Validitas $\mathrm{n}=$ Jumlah nilai maksimal

$\mathrm{f}=$ Jumlah nilai hasil pengumpulan data

Dengan menggunakan rumus tersebut dapat ditentukan capaian keberhasilan dalam pengembangan produk. Di bawah ini merupakan tabel kriteria pencapaian kelayakan :

Tabel 3. 
3871 Pengembangan Aplikasi Mobile Learning Appy Pie Android Berbasis Kemampuan Berpikir Kreatif di Sekolah Dasar - Nur Auliyah, Prima Mutia Sari

DOI: https://doi.org/10.31004/edukatif.v3i6.1127

\begin{tabular}{lc}
\multicolumn{2}{c}{ Kriteria penafsiran angket } \\
Kriteria & 'ersentase (\%) \\
Sangat Layak & $81-100$ \\
Layak & $61-80$ \\
Cukup Layak & $41-60$ \\
Tidak Layak & $21-40$ \\
Sangat Tidak Layak & $0-20$ \\
\multicolumn{1}{c}{ Sumber : (Damayanti \& Dewi, 2021) }
\end{tabular}

\section{HASIL DAN PEMBAHASAN PENELITIAN}

\section{Hasil Penelitian Pengembangan Aplikasi Mobile Learning Appy Pie Berbasis Kemampuan Berpikir Kreatif pada Materi Perubahan Wujud Benda}

Pelaksanaan kegiatan penelitian dilakukan dengan menggunakan model pengembangan ADDIE (Sanjaya dkk, 2015) melalui tahapan - tahapan berikut :

Tahap Analisis (Analysis). Kegiatan yang dilakukan peneliti diawali dengan melakukan observasi dan wawancara pada kelas III pada salah satu sekolah dasar di Jakarta Timur. Pelaksanaan kegiatan observasi ini meliputi analisis siswa, analisis guru dan analisis materi. Berdasarkan hasil observasi kegiatan Pembelajaran Jarak Jauh (PJJ), diketahui bahwa rata - rata 32 siswa menggunakan smartphone sebagai perangkat utama untuk melaksanakan kegiatan pembelajaran di rumah. Kegiatan pembelajaran menggunakan media WhatsApp Grup atau Google Meeting sebagai media dan sarana pembelajaran daring. Namun, di dalam pelaksanaan tidak semua siswa dapat berpartisipasi aktif mengikuti kegiatan Google Meeting karena permasalahan sinyal dan perangkat yang tidak mendukung. Dari hasil wawancara dengan guru kelas, diperoleh permasalahan bahwa guru membutuhkan fitur pendukung untuk memberikan materi pembelajaran kepada siswa. Fitur - fitur yang digunakan oleh guru adalah WhatsApp Grup, Google Meeting dan Google Form. Dalam penggunaan WhatsApp Grup, guru tidak bisa secara maksimal mengontrol kegiatan belajar mengajar. Kendala lain yang dihadapi guru adalah tulisan siswa yang tidak jelas saat mengirimkan tugas individu sehingga guru kesulitan melakukan koreksi dan memberikan evaluasi. Pemilihan materi Tema 3 Benda di Sekitarku Subtema 3 Perubahan Wujud Benda dikarenakan pada materi ini terdapat kegiatan praktikum untuk mengamati proses perubahan wujud benda. Selama pembelajaran jarak jauh, siswa kesulitan dalam melaksanakan kegiatan praktikum secara mandiri Untuk itu, siswa memerlukan petunjuk pelaksanaan kegiatan serta materi yang mendukung untuk mengasah keterampilan dan kemampuan berpikir kreatif siswa. Dari hasil analisis di atas, penelitian ini berupaya mengembangkan aplikasi Mobile Learning Appy Pie. Melalui aplikasi ini diharapkan dapat memaksimalkan kegiatan pembelajaran dan memudahkan guru untuk menyampaikan materi pembelajaran secara lebih praktis dan inovatif.

Tahap Desain (Design). Kegiatan desain sebagai tahap perencanaan produk yang meliputi pembuatan flowchart, penyusunan materi, penyusunan soal, video, gambar atau ilustrasi yang dimasukan ke dalam media pembelajaran melalui Appy Pie. Proses pengumpulan animasi dan ilustrasi media pembelajaran diawali dengan pemilihan color pallete yang disesuaikan dengan tema sekolah dasar. Pemilihan warga yang cerah menjadi ciri khas agar tampilannya menarik bagi siswa. Ilustrasi gambar dirancang sendiri oleh peneliti menggunakan aplikasi canva agar desain disesuaikan dengan kebutuhan tampilan aplikasi mobile learning.

Tahap Pengembangan (Development). Setelah tahap desain dilakukan, langkah selanjutnya adalah melakukan pengembangan aplikasi. Pengembangan aplikasi mobile learning dilakukan pada website resmi www.appypie.com. Bagian menu dikembangkan pada aplikasi mobile learning ini yaitu halaman menu utama, menu petunjuk, menu doa, menu kompetensi, menu peta konsep, menu materi, menu video, menu quiz, dan menu terakhir adalah profil. Berikut tampilan dari aplikasi mobile learning yang telah dikembangkan : 
3872 Pengembangan Aplikasi Mobile Learning Appy Pie Android Berbasis Kemampuan Berpikir Kreatif di Sekolah Dasar - Nur Auliyah, Prima Mutia Sari

DOI: https://doi.org/10.31004/edukatif.v3i6.1127
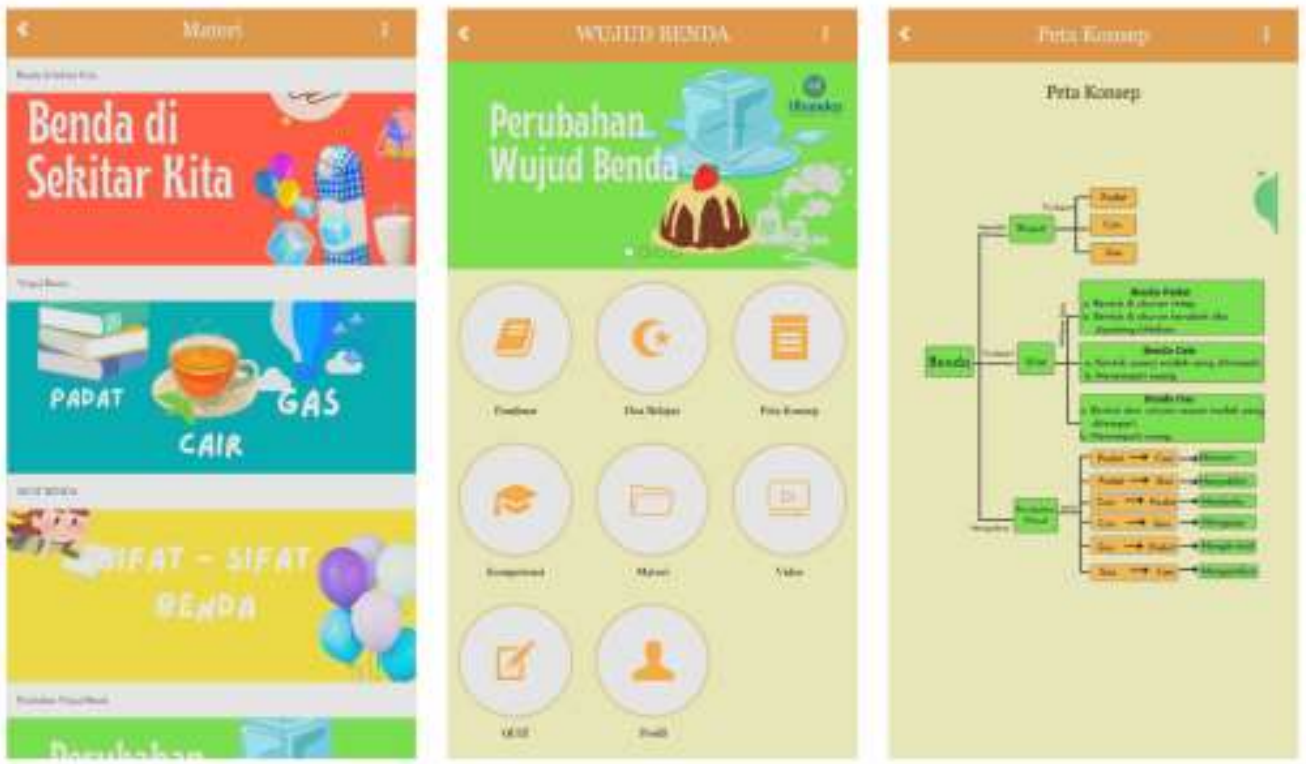

Gambar 2 : Tampilan Aplikasi Mobile Learning pada Menu Utama, Menu Materi dan Peta Konsep
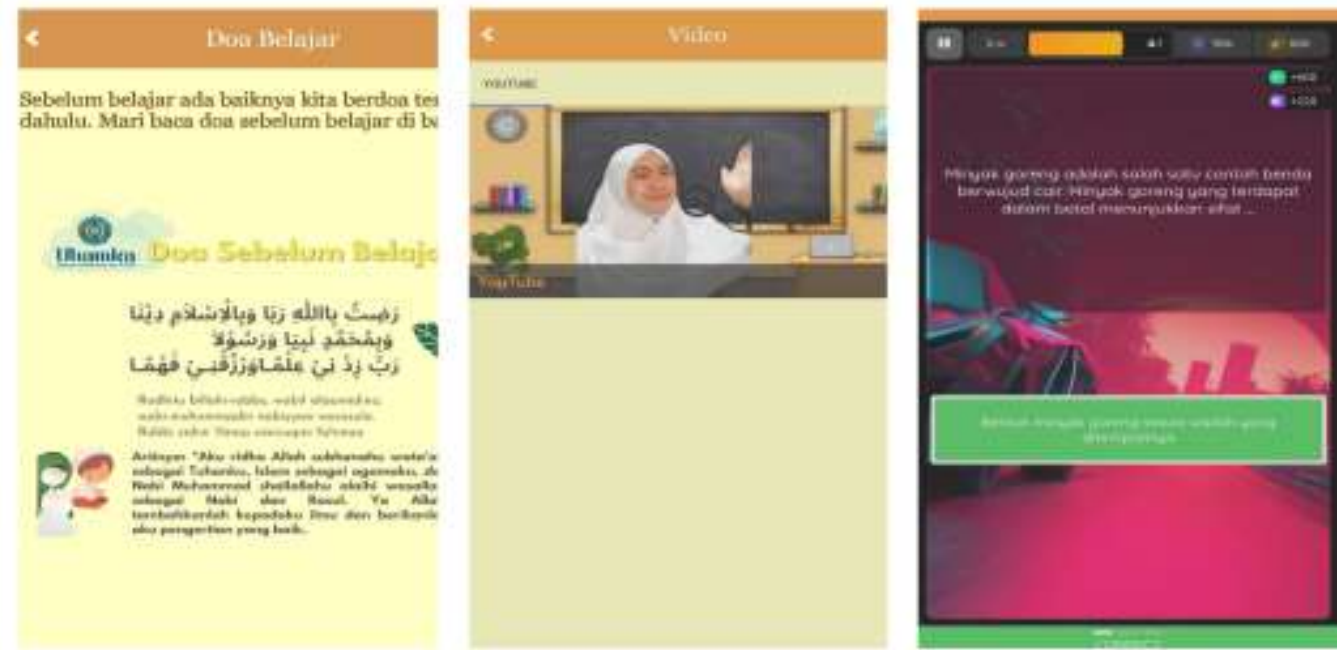

Gambar 3 : Tampilan Aplikasi Mobile Learning pada Menu Doa, Menu Video, dan Menu Quiz

\section{Kelayakan Aplikasi Mobile Learning Appy Pie (Teoritik dan Empiris)}

Hasil validasi dari ahli media terhadap pengembangan aplikasi mobile learning Appy Pie berbasis kemampuan berpikir kreatif pada materi perubahan wujud benda memperoleh hasil penilaian sebagai tabel 4 berikut :

Tabel 4

\begin{tabular}{lcc}
\hline & \multicolumn{2}{c}{ Hasil Validasi Ahli Materi } \\
\cline { 2 - 3 } Aspek & Persentase & $\begin{array}{l}\text { Kriteria } \\
\text { Kelayakan }\end{array}$ \\
\hline Materi & $92.00 \%$ & Sangat Layak \\
\hline Sumber Materi & $90.00 \%$ & Sangat Layak \\
\hline Evaluasi & $80.00 \%$ & Layak \\
\hline Kebahasaan & $92.00 \%$ & Sangat Layak \\
\hline Total Keseluruhan & $354,00 \%$ & - \\
\hline
\end{tabular}

Edukatif : Jurnal Ilmu Pendidikan Vol 3 No 6 Tahun 2021 p-ISSN 2656-8063 e-ISSN 2656-8071 
3873 Pengembangan Aplikasi Mobile Learning Appy Pie Android Berbasis Kemampuan Berpikir Kreatif di Sekolah Dasar - Nur Auliyah, Prima Mutia Sari

DOI: https://doi.org/10.31004/edukatif.v3i6.1127

\begin{tabular}{lcl}
\hline & \multicolumn{2}{c}{ Hasil Validasi Ahli Materi } \\
\cline { 2 - 3 } Aspek & Persentase & $\begin{array}{l}\text { Kriteria } \\
\text { Kelayakan }\end{array}$ \\
\hline $\begin{array}{l}\text { Rata }- \text { Rata } \\
\text { Persentase }\end{array}$ & $\mathbf{8 8 . 5 0 \%}$ & Sangat Layak \\
\hline
\end{tabular}

Penilaian produk oleh ahli materi, diperoleh kualitas aplikasi mobile learning dari tinjauan materi diperoleh persentase sebesar $92.00 \%$ dengan kriteria kelayakan sangat layak, sedangkan pada sumber materi diperoleh penilaian sebesar $90.00 \%$ dengan kategori sangat layak, lalu pada tinjauan evaluasi mendatkan hasil penilaian sebesar $80.00 \%$ dengan kategori layak. Pada tinjauan kebahasaan mendapatkan persentase sebesar $92.00 \%$ yang termasuk pada kriteria sangat layak. Secara keseluruhan, kualitas aplikasi mobile learning dari hasil penilaian ahli validasi materi diperoleh sebesar $88.50 \%$. berdasarkan tinjauan hasil validasi oleh materi ini maka aplikasi mobile learning dinilai sangat layak untuk melanjutkan ke tahap uji coba. Selanjutnya penilaian dari ahli media memperoleh data sesuai tabel 5 di bawah ini :

Tabel 5

\begin{tabular}{lcc}
\hline & \multicolumn{2}{c}{ Hasil Validasi Ahli Media } \\
\cline { 2 - 3 } Aspek & Persentase & $\begin{array}{l}\text { Kriteria } \\
\text { Kelayakan }\end{array}$ \\
\hline $\begin{array}{l}\text { Isi dan } \\
\text { Tampilan }\end{array}$ & $86.67 \%$ & Sangat Layak \\
\hline Kontrol Penggunaan & $93.00 \%$ & Sangat Layak \\
\hline Total Keseluruhan & $179.67 \%$ & - \\
\hline $\begin{array}{l}\text { Rata - Rata } \\
\text { Persentase }\end{array}$ & $\mathbf{8 9 . 8 4 \%}$ & Sangat Layak \\
\hline
\end{tabular}

Perolehan data dari penyajian Tabel 5, penilaian dari validator media pada kategori isi dan tampilan mendapatkan penilaian skor persentase $86.67 \%$ yang dikaetorikan sangat layak. Pada aspek kontrol penggunaan skor persentase sebesar $93.00 \%$ dengan tinjauan kategori sangat layak. Sehingga, persentase rata - rata oleh ahli validasi media memperoleh skor $89.84 \%$ yang masuk dalam kategori sangat layak.

\section{Efektivitas Aplikasi Mobile Learning Appy Pie (Melalui Uji Coba)}

Dalam rangka mengetahui respon siswa mengenai aplikasi mobile learning, maka peneliti melakukan ujicoba kepada siswa yang dilaksanakan pada Senin, 26 Juli 20201. Peneliti berkomunikasi dengan guru untuk melakukan penelitian dalam kondisi pembelajaran jarak jauh (PJJ). Jumlah keseluruhan siswa kelas III pada tempat penelitian adalah sebanyak 32 anak. Persiapan pelaksanaan penelitian uji coba siswa diantaranya yaitu membuat tata cara pengunduhan aplikasi dan tutorial penggunaan aplikasi. Penilaian angket uji coba siswa menggunakan skala Likert 1 sampai dengan 5 pada Google Form yang dikirimkan melalui aplikasi WhatsApp tempat penelitian. Kemudian, siswa diarahkan untuk melakukan pengunduhan aplikasi Appy Pie berbasis Kemampuan Berpikir Kreatif dan menjelaskan fitur - fitur menarik yang ada di dalamnya.

Tahap uji coba oleh guru bertujuan untuk memaksimalkan penggunaan dan peninjauan apakah aplikasi mobile learning yang telah dikembangkan dapat diimplemetasikan dalam kegiatan belajar mengajar siswa. Berikut perolehan data penilaian dan uji coba kelayakan oleh guru :

Tabel 6

\section{Hasil Uji Coba oleh Guru}


3874 Pengembangan Aplikasi Mobile Learning Appy Pie Android Berbasis Kemampuan Berpikir Kreatif di Sekolah Dasar - Nur Auliyah, Prima Mutia Sari

DOI: https://doi.org/10.31004/edukatif.v3i6.1127

\begin{tabular}{lcc}
\hline Aspek & Persentase & $\begin{array}{l}\text { Kriteria } \\
\text { Kelayakan }\end{array}$ \\
\hline Materi dan Pembelajaran & $80.00 \%$ & Layak \\
\hline Media & $95.00 \%$ & Sangat Layak \\
\hline Total Keseluruhan & $175.00 \%$ & - \\
\hline Rata - Rata Persentase & $\mathbf{8 7 . 5 0 \%}$ & Sangat Layak \\
\hline
\end{tabular}

Berdasarkan tabel 6 diperoleh hasil uji coba dan penilaian oleh guru terhadap aplikasi mobile learning Appy Pie berbasis kemampuan berpikir kreatif pada materi perubahan wujud benda pada aspek materi dan pembelajaran sebesar $80.00 \%$ (Layak). Sedangkan pada aspek media diperoleh skor $95.00 \%$. Sehingga rata rata persentase hasil uji coba oleh guru sebesar $87.50 \%$ (Sangat Layak). Selanjutnya tahap uji coba oleh siswa memperoleh data sebagai berikut :

Tabel 7

\begin{tabular}{lcc}
\hline & \multicolumn{2}{c}{ Hasil Uji Coba Oleh Siswa } \\
\cline { 2 - 3 } Aspek & Persentase & $\begin{array}{l}\text { Kriteria } \\
\text { Kelayakan }\end{array}$ \\
\hline Pembelajaran & $76.36 \%$ & Layak \\
\hline Media & $82.13 \%$ & Sangat Layak \\
\hline Total Keseluruhan & $158.49 \%$ & - \\
\hline Rata - Rata Persentase & $\mathbf{7 9 . 2 5 \%}$ & Layak \\
\hline
\end{tabular}

Dari hasil uji coba siswa diperoleh data sesuai tabel 7 dengan hasil dari tinjauan pembelajaran didapatkan hasil perolehan penilaian sebesar $76.36 \%$ yang berarti layak digunakan. Lalu dari segi aspek media memperoleh persentase $82.13 \%$ yang berarti sangat layak. Jika ditotalkan secara keseluruhan lalu dilakukan perhitungan secara rata - rata, maka persentese keseluruhan dari hasil uji coba aplikasi mobile learning Appy Pie berbasis kemampuan berpikir kreatif pada materi perubahan wujud benda dinyatakan layak.

Hasil dari penelitian dan pengembangan ini sejalan dengan penelitian yang telah dilakukan sebelumnya, aplikasi android berbasis pengembangan melalui Appy Pie dengan upaya inovasi untuk dapat meningkatkan minat siswa dalam kegiatan belajar. Melalui media aplikasi Appy Pie siswa dapat mengakses pembelajaran tumbuhan hijau di kelas V sekolah dasar secara lebih mudah dan praktis (Setiani, 2018). Menurut (Khairunnisa \& dkk., 2019), aplikasi pembelajaran mobile learning, memberikan inovasi baru dalam kegiatan pembelajaran di dalam kelas. Aplikasi pembelajaran mudah digunakan sehingga dapat meningkatkan produktivitas yang maksimal walaupun tanpa melakukan usaha yang besar. Selain itu, muatan di dalam mobile learning dikembangkan secara lengkap dengan tampilan yang menarik untuk digunakan.

Selain itu, Penerapan media pembelajaran mobile learning untuk kegiatan belajar mengajar siswa dinyatakan layak untuk digankan karena siswa memberikan respon yang positif terkait penggunaan media pembelajaran mobile learning. Sehingga, aplikasi mobile learning dapat difungsikan sebagai media edukatif dalam pelaksanaan proses belajar dan pembelajaran bagi siswa (Hafipz, 2019). Mobile learning sebagai alternatif pembelajaran yang efektif dan efisien bagi pelaksanaan kegiatan pembelajaran. Bentuk pembelajarannya menggunakan teknologi yang dapat diakses secara mudah kapanpun dan dimanapun.

Sedangkan dalam penelitian (Ardiansyah, 2020), media pembelajaran mobile learning android menjadi salah satu pemecahan masalah agar siswa dapat meningkatkan motivasi belajar serta memberikan dampak positif terhadap peningkatan hasil pembelajaran siswa. Pernyataan tersebut diperkuat oleh (Ardiansyah, 2020), yang menyatakan bahwa m-learning bermanfaat sebagai alat penyajian informasi yang memberikan kemudahan bagi siswa untuk melaksanakan pembelajaran secara lebih efektif tanpa ada batasan tempat dan 
waktu. Penggunaan mobile learning memberikan kemudahan selama kegiatan belajar mengajar baik pada kegiatan belajar efektif di kelas maupun kegiatan pembelajaran secara mandiri di luar kelas. Fungsi dari mobile learning yaitu adanya peningkatan motivasi belajar siswa sehingga materi yang diberikan oleh guru bisa secara mudah dipahami oleh siswa. Siswa juga dapat melakukan pembelajaran secara mandiri dengan bantuan dari mobile learning mobile learning yang telah dikembangkan. Dalam (Henry dkk., 2016) disebutkan bahwa mobile learning menjadi pilihan baru untuk perencanaan dan strategi pembelajaran yang efektif dalam upaya mencapai tujuannya.

Dari rangkaian uraian di atas dipelajari kesamaan penggunaan mobile learning sebagai fasilitas yang memberikan kemudahan dalam kegiatan pembelajaran. Masing - masing penelitian di atas menggunakan mobile learning dengan beragam tujuan diantaranya sebagai media untuk meningkatkan minat belajar siswa, media edukatif dalam kegiatan belajar siswa, meningkatkan motivasi belajar, serta sebagai strategi dalam kegiatan pembelajaran. Sedangkan dalam penelitian ini, pengembangan aplikasi mobile learning Appy Pie diupayakan sebagai media pembelajaran agar siswa dapat belajar secara mandiri dan mengembangkan kemampuan berpikir kreatifnya.

Aplikasi mobile learning Appy Pie berbasis kemampuan berpikir kreatif ini memiliki kelebihan dan keterbatasan dalam penggunaannya. Kelebihan yang diberikan oleh aplikasi mobile learning ini yaitu : (1) Aplikasi mobile learning tersedia dan dapat diunduh pada Play Store; (2) Aplikasi mobile learning membantu peserta didik untuk belajar secara mandiri sehingga penggunaan aplikasi ini bermanfaat selama kegiatan Pembelajaran Jarak Jauh siswa. Sedangkan keterbatasan yang dimiliki oleh aplikasi mobile learning yang telah dikembangkan antara lain : (1) Siswa harus login menggunakan akun email yang terdaftar sebelum dapat mengakses aplikasi mobile learning; (2) Penilaian kemampuan berpikir kreatif siswa hanya berfokusdari hasil penilaian soal yang telah dirumuskan sesuai indikator kemampuan berpikir kreatif; (3) Penayangan video pembelajaran membutuhkan akses internet; (4) Pengguna aplikasi mobile learning ini hanya bisa diakses oleh pengguna operasi handphone android saja.

\section{KESIMPULAN}

Melalui pelaksanaan penelitian ini, maka dapat diuraikan implikasi penelitian yaitu: (1) Penelitian dan Pengembangan (R\&D) aplikasi mobile learning android Appy Pie berbasis kemampuan berpikir kreatif dalam materi Perubahan Wujud Benda pada kelas III di salah satu sekolah dasar daerah Jakarta Timur menggunakan model pengembangan ADDIE (2) Hasil penilaian dari ahli validasi terhadap pengembangan aplikasi mobile learning Appy Pie berbasis kemampuan berpikir kreatif pada materi perubahan wujud benda memperoleh kategori dengan hasil sangat layak dari penilaian oleh ahli materi dan ahli media. (3) Hasil respon guru terhadap aplikasi mobile learning adalah sangat layak sedangkan ditinjau dari respon siswa, memperoleh predikat layak. Dengan demikian pengembangan aplikasi mobile learning Appy Pie berbasis kemampuan berpikir kreatif dalam pembelajaran yang berkaitan dengan materi perubahan wujud benda dinyatakan layak diterapkan di kelas III pada salah sekolah dasar di Jakarta Timur.

\section{DAFTAR PUSTAKA}

Ardiansyah, A. A. (2020). Peran Mobile Learning Sebagai Inovasi Dalam Pembelajaran Di Sekolah. 3(1), $47-56$.

Chusni, M. M., \& Dkk. (2018). Appy Pie Untuk Edukasi. Media Akademi.

Damayanti, N. A., \& Dewi, R. M. (2021). Edukatif: Jurnal Ilmu Pendidikan Pengembangan Aplikasi Kahoot Sebagai Media Evaluasi Hasil Belajar Siswa. 3(4), 1647-1659. 
3876 Pengembangan Aplikasi Mobile Learning Appy Pie Android Berbasis Kemampuan Berpikir Kreatif di Sekolah Dasar - Nur Auliyah, Prima Mutia Sari

DOI: https://doi.org/10.31004/edukatif.v3i6.1127

Hafipz, R. A. K. S. Dan M. K. (2019). Desain Dan Pembuatan Media Pembelajaran Mobile Learning Pada Mata Pelajaran Sistem Dan Instalasi Tata Udara. 6(1), 71-79.

Henry, Muhamad, R., \& Nova, D. (2016). Strategi Pembelajaran Efektif Berbasis Mobile Learning Pada Sekolah Dasar. 0-14.

Indahri, Y. (2020). Permasalahan Pembelajaran Jarak Jauh Di Era Pandemi. Pusat Penelitian Badan Keahlian Dpr R, 19, 13-18. Https://Berkas.Dpr.Go.Id/Puslit/Files/Info_Singkat/Info Singkat-Xii-12-Ii-P3di-Juni2020-201.Pdf

Jannah, M., \& Julianto. (2018). Pengembangan Media Video Animasi Digestive System Untuk Meningkatkan Hasil Belajar Siswa Mata Pelajaran Ipa Kelas V. Pengembangan Media Video Animasi Digestive System Untuk Meningkatkan Hasil Belajar Siswa Mata Pelajaran Ipa Kelas V, 06, 124-134.

Khairunnisa, S., Amirullah, G., \& Ninawati, M. (2019). Jurnal Inovasi Pendidikan Dasar. 4(2), 49-56.

Menteri Pendidikan Dan Kebudayaan. (2020). No Title. Surat Nomor 4 Tahun 2020 Tentang Pelaksanaan Kebijakan Pendidikan Dalam Masa Darurat Penyebaran Corona Virus Disease., 1-3.

Ningsih, R. P. A. Dan N. S. W. (2021). Jurnal Basicedu. Pengembangan Aplikasi Keliling Nusantara Sebagai Media Pembelajaran Tematik Di Sekolah Dasar, 5(4).

Rahmat, H. K. (2019). Mobile Learning Berbasis Appypie Sebagai Inovasi Media Pendidikan Untuk Digital Natives Dalam Perspektif Islam. Tarbawi: Jurnal Pendidikan Islam, 16(1). Https://Doi.Org/10.34001/Tarbawi.V16i1.999

Ratnasari, D., Oktaviyanti, D., Sukmawati, S. S., \& Setiyawati, E. (2020). Pengembangan Mobile Learning Berbasis Program Appypie Untuk Pembelajaran Fisika. Jurnal Penelitian Pendidikan Fisika, 5(2), 158 Https://Doi.Org/10.36709/Jipfi.V5i2.13149

Retnawati, H. (2015). The Comparison Of The Accuracy Of Likert Scale. Jurnal Kependidikan: Penelitian Inovasi Pembelajaran, 45(2), 156-167.

Sanjaya, P., Suwatra, W., Suartama, K., \& Pendidikan, J. T. (2015). Pengembangan Multimedia Interaktif Dengan Menggunakan Model Addie Pada Mata Pelajaran Ips Kelas Viii Semester Ganjil Tahun Pelajaran 2014/2015 Di Smp Negeri 2 Seririt. Journal Edutech Universitas Pendidikan Ganesha Jurusan Teknologi Pendidikan, 3(1). Https://Ejournal.Undiksha.Ac.Id/Index.Php/Jeu/Article/View/4834

Septikasari, R. Dan R. N. F. (2018). Keterampilan 4c Abad 21 Dalam Pembelajaran Pendidikan Dasar. 107117.

Setiani, P., \& Jambi, F. U. (2018). Media Aplikasi Android Pada Pembelajaran Program Studi Pendidikan Guru Sekolah Dasar Media Aplikasi Android Pada Pembelajaran. 1-15.

Setyosari, P. (2015). Metode Penelitian Pendidikan \& Pengembangan (Rendy (Ed.); 4th Ed.). Prenadamedia Group.

Sugiyono. (2018). Metode Penelitian Kuantitatif, Kualitatif, Dan R\&D. Alfabeta.

Widiastika, Milda Asti , Nana Hendracipta, A. S. (2021). Pengembangan Media Pembelajaran Mobile Learning Berbasis Android Pada Konsep Sistem Peredaran Darah Di Sekolah Dasar. Jurnal Basicedu, $5(2), 1060-1066$.

Wiro, M., \& Sulistyowati, R. (2021). Edukatif: Jurnal Ilmu Pendidikan Pengembangan Mobile Learning Berbasis Android Pada Mata Pelajaran Produk Kreatif Dan Kewirausahaan Sekolah Menengah Kejuruan. 3(5), 2092-2104.

Wulandari, D. A., Wibawanto, H., Suryanto, A., \& Murnomo, A. (2019). Pengembangan Mobile Learning Berbasis Android Pada Mata Pelajaran Rekayasa Perangkat Lunak Di Smk Sultan Trenggono Kota Semarang. Jurnal Teknologi Informasi Dan Ilmu Komputer, 6(5), 577. Https://Doi.Org/10.25126/Jtiik.201965994 